\title{
The Investigation on Criminal Acts of Corruption in the Jurisdiction of Rembang Police
}

\author{
Angga Dwi Arifian*) and Sri Kusriyah ${ }^{* *}$ \\ ${ }^{*}$ Rembang Police, E-mail: anggaarifian34@gmail.com \\ **) Faculty of Law, Universitas Islam Sultan Agung (UNISSULA) Semarang
}

\begin{abstract}
This study aims to identify and analyze the investigation of criminal acts of corruption in the Rembang Police Legal Area and the obstacles in investigating corruption crimes in the Rembang Pores jurisdiction and their solutions. The approach method used is sociological juridical, descriptive analytical research specifications, types and sources of data using primary and secondary data, data collection methods are field studies and literature studies, while the data analysis method uses qualitative analysis. The results showed that the investigation of criminal acts of corruption in the jurisdiction of the Rembang Police was carried out in accordance with the provisions of the Criminal Procedure Code through several stages, namely collecting evidence, determining the suspect, examining witnesses and suspects and finally submitting the investigation file, suspects and evidence to the public prosecutor. In the investigation process there are several obstacles faced, namely the length of the process of collecting evidence, the suspect providing convoluted information, returning the case file by the public prosecutor.

Keywords: Investigation; Corruption Crime; Public Prosecutor.
\end{abstract}

\section{Introduction}

Article 1 paragraph (3) of the 1945 Constitution of the Republic of Indonesia states that the state of Indonesia is a state of law, so that there are several consequences to it. Law is a collection of coercive regulations that determine human behavior in society, which are made by official state bodies and contain strict sanctions for these regulations. ${ }^{1}$

Every citizen's actions are regulated by law, each aspect has its own rules, provisions and regulations. The law stipulates what to do, what to do and what not to do. One of the crimes that are very detrimental to the state is corruption.

The spirit and efforts to eradicate corruption in the reform era were marked by the issuance of various products of legislation, namely MPR RI Decree No. XI/MPR/1998 concerning the Implementation of a State that is Clean and Free from Corruption, Collusion and Nepotism, Law of the Republic of Indonesia Number 28 of 1999 concerning Implementation of a State that is Clean and Free from Corruption, Collusion and Nepotism, Law of the Republic of Indonesia Number 31 of 1999 concerning Eradication of Criminal Acts of Corruption as amended by Act No. 20 of $2001 .^{2}$

\footnotetext{
1Ishaq, Dasar-Dasar Ilmu Hukum, Sinar Grafika, Jakarta, p. 3.

2 Yusi Amdani, Formulasi Hukum Pidana Terkait Pertanggung Jawaban Pidana Korporasi Dalam Tindak Pidana Korupsi, Jurnal Hukum Samudra Keadilan, Volume 12, Number 2, July-December 2017, p.188.
} 
Law enforcement efforts against criminal acts of corruption in Indonesia are still experiencing significant difficulties, so that efforts to prevent and eradicate corruption need to be carried out continuously and continuously and need to be supported by various resources, both human resources and other resources such as increasing institutional capacity and increasing law enforcement in order to raise awareness and attitudes of anti-corruption public actions. ${ }^{3}$

Corruption still ranks high, where data from ICW records that throughout 2020 there were 1,218 corruption cases tried at the Corruption Court, High Court and Supreme Court. The total number of defendants in corruption cases in 2020 reached 1,298 people. From this data, it is noted that the most corrupt practices were carried out by the State Civil Apparatus (ASN) with 321 cases, the private sector with 286 cases, and village officials with 330 cases. ${ }^{4}$

At the Rembang Police, every year, 2 cases of corruption are handled. In this case, the investigator has a difficult task to find the truth by collecting evidence of the occurrence of a crime, by conducting investigations and investigations. ${ }^{5}$ Law enforcement, including criminal law enforcement is a series of processes of applying abstract legal values, ideas and ideals into legal goals. ${ }^{6}$ As part of criminal politics, the general purpose of criminal law in all its aspects is the protection of society to achieve public welfare. ${ }^{7}$

Police as specified in Article 30 paragraph (4) of the 1945 Constitution of the Republic of Indonesia is an instrument of the state that maintains security and public order with the task of protecting, nurturing, serving the community and enforcing the law. In this case, the National Police has a role in maintaining public security and order, enforcing the law, and providing protection, protection, and services to the community in the context of maintaining domestic security (Article 5 of Act No. 2 of 2002 concerning the Indonesian National Police).

The police have a very important role in handling corruption crimes through the process of investigation and investigation. The Criminal Procedure Code provides the definition of an investigation as a series of actions by an investigator in terms of and according to the method regulated in this law to seek and collect evidence which with that evidence makes clear about the criminal act that occurred and in order to find the suspect. The results of the investigation will be the initial evidence as the basis for the prosecution to make the investigation

\footnotetext{
3 Susilawati, Peran Penyidik Polri Dalam Pencegahan Dan Penegakan Hukum Tindak Pidana Korupsi (Studi Penelitian Direktorat Reserse Kriminal Khusus Kepolisian Daerah Sumatera Utara), Jurnal Hukum Kaidah, Voume 19, Nomor 1, 2019, p.51

4 Data ICW 2020 Kerugian Negara Rp 567 Triliun Uang Pengganti dari Koruptor Rp 8,9 Triliun, https://nasional.kompas.com, accessed May 21, 2021.

5 Results of an interview with Brigadier Muhammad Asroni as the Rembang Police Satreskrim Banit, dated June 2, 2021.

'Sulaiman (Ed.), 2016, Pemikiran Hukum Spiritual Pluralistik, Sisi Lain Hukum yang Terlupakan, Cetakan Kedua, Yogyakarta: Thafa Media, Yogyakarta, p. 313.

7 Sri Endah Wahyuningsih, 2013, Prinsip-Prinsip Individualisasi Pidana Dalam Hukum Pidana Islam dan Pembaharuan Hukum Pidana Indonesia, Semarang: Badan Penerbit Universitas Diponegoro, Semarang, p.91.
} 
process a legal process that should be observed. ${ }^{8}$ This study aims to identify and analyze the investigation into criminal acts of corruption in the Rembang Police Legal Area and the obstacles in the investigation of corruption in the Rembang Pores jurisdiction as well as the solutions.

\section{Research Method}

The approach method used in this research is sociological juridical, namely: research based on normative legal science and examines how the law works in society. ${ }^{9}$ The research specification is analytical descriptive, the sources and types of data used are primary data and secondary data. The data collection method is carried out through field studies and literature studies while the data analysis method uses qualitative analysis.

\section{Results and Discussion}

\subsection{Investigating Criminal Acts of Corruption in the Legal Territory of Rembang Police}

According to Sudarto, as quoted by Aziz Syamsudin, literally the word corruption refers to corrupt, rotten, dishonest actions related to finances. ${ }^{10}$ Meanwhile, according to Victor M. Situmorang, corruption is generally said to be an act with the intention of enriching oneself or another person or an entity that directly or indirectly harms state or regional finances or the finances of an agency that receives state financial assistance, in which the act is carried out with abuse his position/authority. ${ }^{11}$ As for the types of criminal acts of corruption, it has been regulated in Act No. 31 of 1999 in conjunction with Act No. 20 of 2001, which includes Articles 2 to 13.

Corruption is the use of public office for purposes other than official interests. Corruption itself consists of various types: bribery, extortion, peddling influence, nepostism, fraud, bribery, embezzlement and so on. People tend to see corruption only as a sin in the eyes of the government, but in fact there are many private parties involved in corruption in the government sector. ${ }^{12}$

Corruption has developed in accordance with the development of society and information technology from the old order to the reform era. This was also followed by changes and adjustments to the law on eradicating corruption in

\footnotetext{
8Tito Satria Perdana, 2019, Peran Penyidik Utama Satuan Reskrim Polsek Gamping Dalam Upaya Penurunan Tingkat Kriminalitas di Wilayah Hukum Polsek Gamping, Tesis, Yogyakarta : Univesitas Janabadra, p. 5.

9 Mukti Fajar ND dan Yulianto Achmad, 2013, Dualisme Penelitian Hukum Normatif dan Empiris, Yogyakarta: Pustaka Pelajar p.47.

${ }^{10}$ Aziz Syamsuddin, 2013, Tindak Pidana Khusus. Jakarta: Sinar Grafika, p. 137

11Victor M. Situmorang. Tindak Pidana Pegawai Negeri Sipil. Jakarta: Rineka, 1994, p. 1

12 Luk Har Syan'ini, Gunarto and Widayati, Criminal Investigation Polres Kudus Unit Efforts In The Prevention Of The Corruption In Village Funds Management, Jurnal Daulat Hukum, Volume 2 Issue 1, March 2019, p.71
} 
Indonesia in accordance with the development of the mode of occurrence of acts of corruption. ${ }^{13}$

Based on the results of research at the Rembang Police, the investigation of criminal acts of corruption is no different from the investigation of other criminal acts. Investigations into criminal acts of corruption are based on the provisions of Criminal Procedure Code (KUHAP) which includes the stages of collecting evidence, determining the suspect, examining witnesses and submitting the results of the investigation.

Investigators take a series of actions to determine an event that is suspected of being a criminal act (investigation), which is then followed by searching and collecting evidence to make light of the crime that occurred (investigation). The police must obtain strong evidence to bring the suspect to trial, while still prioritizing the presumption of innocence. In handling corruption crimes, if a hand arrest operation is carried out, then arrests and detentions are carried out. However, if it begins with a complaint, an audit must be carried out from the BPK or BPKB or the inspectorate to determine the amount of loss first and then the investigation process is carried out. In practice, the process of investigating criminal acts of corruption is often constrained in filing so that the investigation process becomes slow. ${ }^{14}$

The stage of collecting evidence is carried out by Polri investigators, which begins with obtaining information or allegations of a criminal act of corruption committed by someone. Sources of information can come from the findings of the National Police from investigation activities, reports from the general public, and reports from BPKP (Financial and Development Audit Agency). The results of the collection of evidence can be in the form of information about the type and form of corruption, the time and place of the execution of the crime, the tools used to commit the crime, the motive for committing the crime, and then the information is used by investigators to find the suspect.

On the basis of the evidence that has been collected, the investigator can determine who the perpetrator is to be made a suspect, for further examination. In examining the existing evidence, it will be related to the criminal act committed by the suspect, so that it becomes clear that the suspect is the culprit and the criminal provisions are in accordance with the suspect's actions as regulated in Act No. 20 of 2001 concerning Amendments to Law of the Republic of Indonesia Number 31 of 1999 concerning Eradication of Corruption Crimes. In addition to examining suspects, investigators also dig up information from witnesses to complete the evidence that has been collected. ${ }^{15}$

The results of investigations into cases of criminal acts of corruption are recorded in the minutes of examination to be submitted to the Public Prosecutor

\footnotetext{
${ }^{13}$ Hulman Siregar, Rumusan Pidana Dan Pemidanaan Tindak pidana Korupsi Yang Merugikan Keuangan Negara Serta Permasalaan Dalam Penerapannya, Jurnal Daulat Hukum Vol. 1. No. 1 March 2018, p. 129.

${ }_{14}$ Results of an interview with Ipda Widodo Praseetyo as Head of Idik 3 Tipidkor Rembang Police Satreskrim, June 30, 2021.

15 Ibid
} 
for further examination. The submission of the minutes of examination is carried out in two stages, namely:

- In the first stage, investigators only submit case files to the Public Prosecutor.

- The second stage is handing over responsibility for the suspect and his evidence to the Public Prosecutor.

After the dossier of the results of the investigation and the suspect along with the evidence are submitted to the public prosecutor, the investigation process is declared complete. Furthermore, the public prosecutor will carry out prosecutions for the benefit of the trial.

\subsection{Obstacles in Investigation of Criminal Acts of Corruption in the Legal Area of Rembang Police and Solutions}

Based on the results of research and interviews with investigators, the obstacles faced by investigators in investigating criminal acts of corruption in the jurisdiction of Polwiltabes Semarang are as follows: ${ }^{16}$

- Difficult and lengthy process of collecting evidence of criminal acts

The process of collecting evidence of criminal acts of corruption sometimes takes a long time, while the time for investigation has already been determined. This makes it difficult for investigators to complete the investigation until the filing. The solution to overcome these obstacles is to collaborate with parties who can provide clarity regarding evidence of criminal acts. In addition, investigators also collect as much evidence as possible, especially in the form of statements from witnesses. From within Polri itself, efforts have been made to improve human resources through education and training to support the professionalism of investigators' work.

- The suspect gave convoluted information.

In the process of examining suspects, suspects often provide convoluted and unclear information, and often forget to answer. The solution to overcome these obstacles is to approach the suspect in order to provide clear information and encourage the suspect to cooperate during the investigation process.

- The dossier of the examination is returned by the public prosecutor

Examination case files are often rejected by the public prosecutor because there are still some things that need to be fixed. Case files can be returned several times to meet the requirements for transferring the case to the public prosecutor. This is getting more and more time consuming. The solution to overcome these obstacles is to make improvements to the case file in accordance with the instructions and directions from the prosecutor.

\section{Closing}

Investigation of criminal acts of corruption in the jurisdiction of the Rembang Police is carried out in accordance with the provisions of the Criminal Procedure Code through several stages, namely collecting evidence, determining the suspect, examining witnesses and suspects and finally submitting investigation

\footnotetext{
16 Ibid.
} 
files, suspects and evidence to the public prosecutor. In the investigation process, there are several obstacles faced, namely: the length of the process of collecting evidence, the suspect providing convoluted information, returning the case file by the public prosecutor. In order for the investigation process of corruption in the jurisdiction of the Rembang Police to be more optimal, it is necessary to have special training and education for corruption investigators to improve professionalism.

\section{References}

\section{Journal}

[1] Yusi Amdani, Formulasi Hukum Pidana Terkait Pertanggung Jawaban Pidana Korporasi Dalam Tindak Pidana Korupsi, Jurnal Hukum Samudra Keadilan, Volume 12, Nomor 2, July-December 2017.

[2] Susilawati, Peran Penyidik Polri Dalam Pencegahan Dan Penegakan Hukum Tindak Pidana Korupsi (Studi Penelitian Direktorat Reserse Kriminal Khusus Kepolisian Daerah Sumatera Utara), Jurnal Hukum Kaidah, Voume 19, Nomor $1,2019$.

[3] Luk Har Syan'ini, Gunarto and Widayati, Criminal Investigation Polres Kudus Unit Efforts In The Prevention Of The Corruption In Village Funds Management, Jurnal Daulat Hukum, Volume 2 Issue 1, March 2019.

[4] Hulman Siregar, Rumusan Pidana Dan Pemidanaan Tindak pidana Korupsi Yang Merugikan Keuangan Negara Serta Permasalaan Dalam Penerapannya, Jurnal Daulat Hukum Vol. 1. No. 1 March 2018.

\section{Book}

[1] Aziz Syamsuddin, 2013, Tindak Pidana Khusus. Jakarta: Sinar Grafika.

[2] Ishaq, Dasar-Dasar Ilmu Hukum, Sinar Grafika, Jakarta, 2012.

[3] Mukti Fajar ND dan Yulianto Achmad, 2013, Dualisme Penelitian Hukum Normatif dan Empiris, Yogyakarta: Pustaka Pelajar.

[4] Sri Endah Wahyuningsih, 2013, Prinsip-Prinsip Individualisasi Pidana Dalam Hukum Pidana Islam dan Pembaharuan Hukum Pidana Indonesia, Semaang : Badan Penerbit Universitas Diponegoro, Semarang.

[5] Sulaiman (Ed.), 2016, Pemikiran Hukum Spiritual Pluralistik, Sisi Lain Hukum yang Terlupakan, Cetakan Kedua, Yogyakarta : Thafa Media, Yogyakarta.

[6] Tito Satria Perdana, 2019, Peran Penyidik Utama Satuan Reskrim Polsek Gamping Dalam Upaya Penurunan Tingkat Kriminalitas di Wilayah Hukum Polsek Gamping, Tesis, Yogyakarta : Univesitas Janabadra

[7] Victor M. Situmorang. 1994, Tindak Pidana Pegawai Negeri Sipil. Jakarta: Rineka Cipta.

\section{Regulation}

[1] 1945 Constitution of the Republic of Indonesia

[2] Criminal Code

[3] Criminal Procedure Code

[4] Act No. 2 of 2002 concerning the Indonesian National Police. Jakarta, 2002 
[5] Act No. 20 of 2001 concerning Amendments to Law of the Republic of Indonesia Number 31 of 1999 concerning Eradication of Criminal Acts of Corruption.

\section{Internet}

Data ICW 2020 Kerugian Negara Rp 567 Triliun Uang Pengganti dari Koruptor Rp 8,9 Triliun, https://nasional.kompas.com, accessed on 21 May 2021. 